\title{
John Bell (1796-1868)
}

John Bell, discoverer of the Yukon River and associate of Drs. John Richardson and John Rae in the Franklin search expedition of 1847-1849, represented the classic blend of fur trader and explorer. His contributions to the expansion of the Company's trade in the far northwest and to the cause of arctic exploration have gone largely unnoticed, due in some measure to his unassuming and modest character.

Bell was born on the Isle of Mull in 1796. Like many young men from Scotland, he was attracted by the North American fur trade, joining the North West Company as a clerk in 1818. His northern career began in 1824 when, as an officer of the reorganized Hudson's Bay Company, he was transferred to the Mackenzie District. In 1837, Thomas Simpson and Peter Warren Dease had discovered the Colville River on the arctic coast. Anxious to exploit this find, Governor Simpson ordered that John Bell, by now an experienced northern trader, attempt to locate an overland route joining the Mackenzie and the Colville.

In 1839, Bell travelled along the lower reaches of the Peel River, looking for a breach in the mountains that would take him west. Though he did not immediately succeed, his reports of the excellent prospects for trade encouraged the Company to establish a trading post. Bell opened Peel's River Post, later renamed Fort McPherson, in 1840. On Governor Simpson's directions, he also continued his explorations of the lands west of the Mackenzie.

The task proved more difficult than expected, largely because the local Indians, anxious to protect their monopoly over the Peel's River trade, offered little help in the push to the west. Several times Bell had to cancel or abort expeditions when the natives hired to guide the Company's men across the divide refused to continue. Bell crossed the mountain range in 1842

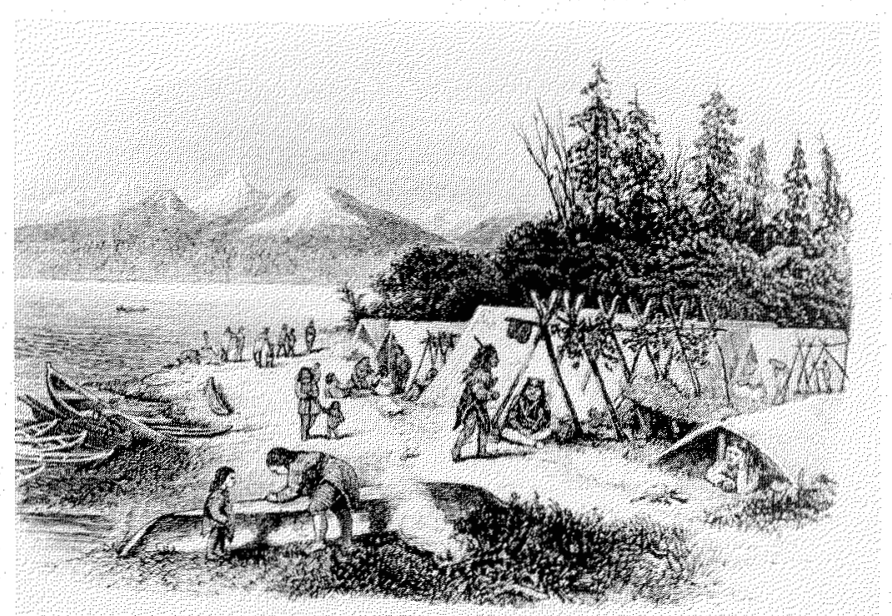

A summer Indian encampment on the Yukon River. Bell's explorations west of the Mackenzie and into the Yukon watershed brought such bands within the HBC's trading network. Both illustrations are from Frederick Whymper's Travel and Adventure in the Territory of Alaska (1868). and descended some distance down the Bell River. He was convinced, however, that the route was not feasible for trading and turned back. The Hudson's Bay Company was determined to press its advantage in the area, however, and Bell was ordered to extend his explorations. He did so in the summer of 1845 , when he reached the junction of the Porcupine and Youcon rivers. Plans were immediately set in motion for a new trading post on the new river, and in 1847 Alexander Hunter Murray opened Fort Youcon.

Bell's work on exploration was not done. The Hudson's Bay Company took an active part in the attempt to locate the lost Franklin expedition. In 1847, Governor Simpson assigned John Bell to assist with an expedition, led by Drs. John Richardson and John Rae, that searched the coast between the Mackenzie and Coppermine rivers. Bell's primary responsibility was to provide logistic support for the venture; during 1848, for example, Bell built Fort Confidence on Great Bear Lake as a wintering station for the expedition. At the completion of Richardson and Rae's journey, Bell returned to his fur trade duties and was assigned to Fort Liard.

Bell's name has not taken a prominent place in the annals of northern exploration. Many northern explorers rushed descriptions of their travels into print, anxious to share news of their discoveries and to bask in the fame due a northern explorer. Bell did not, offering lengthy accounts in his letters to HBC officers, but making little effort to spread his story further. He tackled these duties without the enthusiasm and sense of destiny that inspired other $\mathrm{HBC}$ explorers. He was, in fact, a fur trader rather than an explorer, both in talent and temperament. Throughout his northern career, he placed primary importance on the organization and management of the trading posts he commanded, and although he accepted the exploration assignments with few complaints, he preferred the life of a fur trader.

He was less pleased with the northern postings he received through much of his career. Although he was hestitant to complain too loudly, he did make known his displeasure with being sent to "this dismal and secluded part of the country." Bell often despaired at his isolated location, the lack of companionship, and the unattractiveness of the northern environment. As he wrote at one point, "I am as usually the case with me in this miserable and distant part of the country, a bankrupt for news of any kind. Where my friend shall I glean any? from the Indians, animals or Fowls of the air." He longed for transfer to a more salubrious climate, but because of his talent and experience, the Company was loath to move him south.

John Bell did not have the commanding presence of other major northern explorers. He was a quiet man, well liked by his colleagues in the fur trade, and noted for his abilities as a manager of men. His skills were those of the fur trade officer; he took orders well, demonstrated notable loyalty to the Company, was a fair and consistent commander, and sought corporate approval rather than public fame during his years in the North. From the HBC's perspective, Bell was one of their most useful officers - accounting for his long and often miserable tenure in 


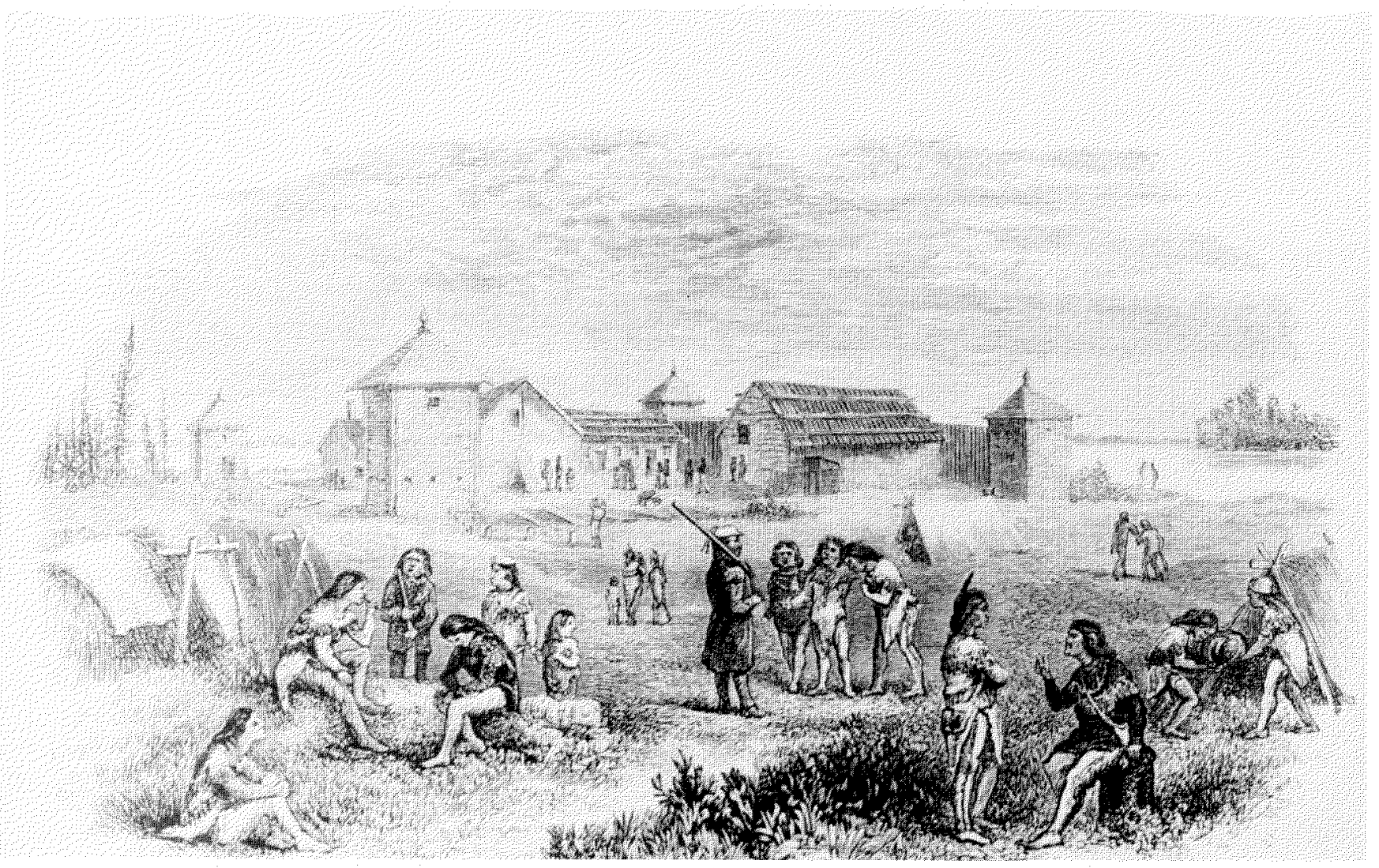

Fort Youcon. This HBC post, situated where the Porcupine flows into the Yukon River, opened in 1847, two years after Bell's exploration of the region.

the North - because of his professionalism, flexibility, and dedication to the interests of the fur trade.

Bell remained in the North until 1851 , when he was transferred to the Cumberland District. He later moved to Sept Iles, near Quebec City, where he stayed until he retired. He left the Company's service in 1860 and moved to Saugeen, Ontario, where he died in 1868.

\section{FURTHER READINGS}

KARAMANSKI, THEODORE. 1983. Fur Trade and Exploration: Opening the Far Northwest, 1821-1852. Vancouver: University of British Columbia Press.

RICHARDSON, JOHN. 1851. Arctic Searching Expedition: a journal of a boat-voyage through Rupert's Land and the Arctic Sea, in search of the discovery ships under command of Sir John Franklin. London: Longman, Brown, Green, and Longmans.

WRIGHT, ALLEN. 1976. Prelude to Bonanza: The Discovery and Exploration of the Yukon. Sidney, B.C.: Gray's Publishing.

Kenneth S. Coates

Department of History

Brandon University

Brandon, Manitoba, Canada

R7A 6A9 